\title{
THE POSITION OF RELIGIOUS MINORITIES IN INDONESIA'S DEMOCRATIC TRANSITION: A STUDY TOWARD CRITICAL OVERVIEW
}

\author{
M. Regus \\ St. Paul of Ruteng Indonesian Catholic University, Flores \\ <max.regus73@yahoo.com>
}

\begin{abstract}
The problems of democratic transition as a context of this study will be analyzed. Also, violence and political exclusion of religious minority group will be explained. At the end of the chapter, the possibility of political will and legal solutions for violence against religious minority groups in Indonesia in the post-1998 era are discussed. It is explained that a comprehensive legal protection scheme would be needed to realize the rights of religious minorities in Indonesia. One of the fundamental purposes of democratization in the post-authoritarian era is thus shown to be the protection of religious minority groups. The chapter will first discuss the problem of democratic changes with focus on the politics of decentralization and the critical practice of civil democracy, which will all be explored, the two of significant changes affecting the position of religious minorities in Indonesia. The chapter will then consider the exclusion of religious minorities and the failure of the 'democratic'state to protect their basic citizenship rights. Next, the role of the state and of civil society in the implementation or non-respect of legal protection for religious minority communities will be considered based on critical overview.
\end{abstract}

Keywords: Indonesia, religious minorities, democratic transition, Justice

\section{Introduction}

Conceptually, minorities are described as the sub-dominant groups. This can be characterized by various categories of either ethnic, political or religious aspects. In many cases, they are less able to maintain and protect their position in dealing with the majority groups [1]. Religious minorities as a national minority are vulnerable groups in Indonesia [2]. Certain members of religious minorities 
continually face violence in Indonesia. For some cases, they are considered non-citizens and stateless people [3].

It is well agreed that the extend brutal attacks against religious minority groups demand the state intervention [4]. In this term, the political responsibility of the state (government) defines the position that can be constructed and should be provided by the state. In this context, the state has the opportunity for becoming a part of the solutions to the problems - or they merely to be a part of the problems. The political position of the state deals with such a negative assessment related to the state's response to violence against certain members of religious minority communities.

The members of religious minority groups can be violated owing to a political uncertainty within the state bodies. Theoretically, at this point, the state is obliged to implement a more practical strategy in supporting religious minority groups. The state should construct a strong political interest rather than manage formal prerequisites of democracy. The state has a main duty in solving serious problems related to contemporary social and political dynamics that affect the position of religious minority groups in Indonesia.

Yet, it is also hoped that Indonesia's government has to build the right track for constructing a strong political standpoint for implementing a regulatory system of protection to religious minorities. It is based on the fact that religious minorities are facing uneven and massive violence because of the state political weakness in guaranteeing the enjoyment of basic rights by religious minorities groups. At this point, the state should be able to achieve legal and political commitment to appreciate and to protect religious minority groups.

By now, Indonesia should answer one of the crucial questions about the position of religious minorities in the phase of democratic transition. In this political phase, substantively, a peaceful political atmosphere in which religious minorities gain democratic benefits requires the direct action of the state by implementing sets of political protection. Accordingly, the state has to build political consistency to achieve a promising democratic process. The process focuses on a building of democratic society as an important arena for religious minorities to enjoy political certainties in expressing basic rights and especially the freedom of expression. Along these lines, Indonesia's case shows a critical situation in which religious minorities groups are hardly struggling for protection from an ongoing violence and discrimination.

\section{Defining the empirical context}

The transition session relates to the fall of President Suharto who had political power in Indonesia since 
1966 until 1998. This political session was known as Suharto's authoritarian regime. The absolute power of Suharto had been manifested in many forms of political and democratic practices: restrictions on the press, a political monopoly through political parties, the presidential family business, and violation of pro-democracy activists. An absolute power of the Suharto regime had been implicated in aspects of social, political, and cultural. The economic crisis uppercut Southeast Asia and Indonesia in 1997, growing discontent from the public.

This situation continued to strengthen rapidly in the form of massive protests and demonstrations by students throughout 1997 to 1998 . Suharto handed over power to Vice President BJ Habibie on the date of March 21, 1998. Massive protests by Indonesian students and many elements of civil society opened up a new opportunity for Indonesia to redefine a strategy for democratization, providing the basis to introduce people's participation in the political arena [5].

One important variable that must be considered in this respect is the development of political networks between religious minorities and their political representatives in all levels and scopes. Democracy that principally guarantees the presence of religious minorities has become just a "political myth' in the absence of the political interest of political representatives in constructing a protection framework for them. The connectivity between religious minorities and the political institutions as a result of electoral democracy demands a strong implementation of the basic principle of democracy. Tragically, violence and discrimination have tended to increase the basis of a lack of political interest from the democratic institution in Indonesia.

Another important issue is still there. The principle that democracy offers a political opportunity for constituents and the political deliberation process in which minorities have a chance to be involved in the political process and space does not produce political benefits for religious minorities, according to the case that the majority demonstrate a domination power. Substantive aspects of democracy, which provides opportunities for the participation of minority groups, face challenges in the shadow of the majority domination [6].

In this transitional phase, democracy (democratization) has been a dominant discourse in Indonesia. However, one significant aspect that should be used to measure positive achievements of the electoral democracy is the state's interest and capacity to construct a social space without violence against minority citizens including religious minorities. The argument focuses on the political will within state institutions in realizing 
the basic needs and rights of religious minority groups, considering each religion's needs to live in peace.

This is not only connected with the legalization process of their presence but also links with the dynamics of a religious minority group. The state should take a political opportunity for reducing social intolerance against religious minorities through an adoption a decisive political position beyond particular interest. The main basic stance behind this political pathway refer to the achievement of social welfare, freedom of expression, civil liberties, the political participation of citizens, and strong political interest in the poor society.

Yet, democratic transition offers both political opportunities as well as presents challenges for Indonesia. In the positive view, it can be said that democratic transition comes up with a large number of societal-political promises for the Indonesian public such as a multi-party system, decentralized political development, civil liberties, and freedom of the press. But, some scholars conclude that Indonesia is experiencing democratic transition in an uncertain way. Relating to the implementation of justice for the religious minority, there are important phenomena related to the democratic transition in Indonesia [7].

\section{Critical implications of Electoral Democracy}

This section discusses an interlinking between the practice of electoral democracy and the status of religious minorities in Indonesia. Indonesia has implemented a representative democracy since 1998 with a multi-party system, which became one of the most important aspects used to support the electoral democratic model in Indonesia. Indonesia, since 1999, has held several elections within the framework of electoral democracy [8].

The fundamental principle that cannot be denied in this context is that the direct participation of people (the citizens) reflected on one of the key prerequisites for an electoral democracy —offering a wider space for the public to enjoy the benefits of democratic values.

The Challenge of deepening democracy - that is, the contemporary project of developing and sustaining more substantive and empowered citizen participation in the political process than what is normally found in liberal representative democracy alone [9].

Individuals and social groups have the same opportunity to form social (political) organizations, develop various and diverse political affiliations with many political parties and express their political interests [10].

In theory, a multi-party system should offer greater opportunity than a one-party state for people to participate in politics. In theory, citizens should get 
more chances to express their political interests and be more able to control and evaluate public policies implemented by the government. This new democratic mechanism offers a wider chance for the public to demand a fair political process under a strong political participation. People have access to the potential means to construct policy that accommodates their political interest and social needs [11].

In accordance with the direct participation of people in electoral democracy, constituency is a complex issue. Representative democracy demands a constituency as a central issue in an electoral democracy. The degree of participation of people (citizens) could be conducted into the mechanism of a representative democracy. According to this definition, individuals have basic rights in determining the implementation of a representative democracy. However, a constituency is not only connected with a direct participation but is also related to the fulfillment of social and political rights. This is a real challenge to Indonesia's belief on democracy when certain members of religious minorities are living under social and political pressure.

Furthermore, political participation within an electoral democracy constructs a political representation, as an example a parliamentary institution. Thus, a constituency is not only associated with the direct participation of people but is also correlated with political contact between people and their representatives, which is associated with the institutionalization of democracy and public interest. As a result of electoral democracy, the government and parliament have to implement public interest within the public policy framework.

In Indonesia, the state in context of electoral democracy often faces a public distrust due to its neglect of essential issues such as religious freedom-placing democracy after a precarious session. One important question which has already arisen in an association with series of violence against religious minorities is whether an electoral democracy has a sufficient power to challenge these tendencies, or alternatively whether it precisely offers a negative contribution towards the growing violence against religious minorities [12]. In Indonesia, the main principles of democracy such as equal justice for all citizens and political protection for religious groups are moving to a period of zero public expectations [13].

Indonesia is still facing many challenges and serious problems in implementing the basic principles of democracy, with the public largely maintaining the perception that democracy in Indonesia has been taken under bias structure, with no boundaries and fundamental rules to minorities groups. Thus, it is argued 
that one important aspect that should be used as a variable to analyse the efficacy of democratic process in this transitional phase is the contemporary situation of religious minority in Indonesia [14]. This perception is based upon public concerns over the lack of political empowerment of the state and institutions of democracy to protect religious minorities. In fact, the story on positive achievements of democratization after Suharto's regime in Indonesia expresses political lies [15].

\section{The Place of Religious Minorities in the Democratic Transition}

I am now moving to the central element of this paper. There is undeniable fact that the situation of religious minorities becomes a critical discourse in Indonesia's democratic transition. Certain members of religious minorities face brutal attacks, social discrimination, and violations. This situation has led to religious minorities being unable to enjoy the socio-politico benefits of a democratic transition. It is noteworthy to state that religious minorities in Indonesia are still fighting for justice and equality toward peace living and their existence-especially in obtaining the right to express their existence and a freedom of belief.

In this case, democracy relates to the position of the state in supporting other groups to share a space for religious minorities. Religious minorities are facing many problems by referring on Blair's opinion;

The challenge is that much greater where human dignity is not respected and freedom of religion is denied - all have suffered, in some measure, from different discrimination - from glass ceiling harassment, persecution and systematic repression [16].

Inclusive justice relates to the ease of religious minorities in expressing their beliefs. The position of the state in relation to the situation of religious minorities also becomes an important issue in this case.

\section{Political exclusion and the problem of} violence

In Indonesia, the presence and the freedom of expression of religious minorities are in a dangerous situation. Violence against religious minorities and their political exclusion are connected in several ways, as this section seeks to illustrate. Both violence and political exclusion are important issues when dealing with the place of religious groups under a democratic transition. If violence limits access to the political process, then public policy and political institutions will tend to neglect the protection of minorities in democratic states controlled by the majority.

Religious minorities experience political exclusion. Political exclusion not only reinforces violence, however, it can also lead to minorities struggling to protect their citizenship rights within the democratic arena between state and civil society. Religious minorities, 
even those who are citizens, thus face a problematic situation due to the domination of the majority in the political process. The problem of violence will be outlined, and then it will be linked with political exclusion.

It is widely agreed that violence and discrimination against religious minority groups is a sensitive phenomenon in a time of democratic transition. Discrimination against religious minority groups also describes a social intolerance in Indonesia. At the moment, religious minority groups frequently experience attacks due to a difference in a basis of spiritual beliefs. At this point, social intolerance is not limited to the rights of religious groups to build and have property or a place for worship but also in the their entire existence. Thus, it can be explained that social restrictions are connected to the existence of religious minority groups [17].

\section{Massive violence experienced} by religious minority groups in contemporary situations reflects the prolong failure of the democratic government to guarantee religious minority groups in Indonesia [18]. Government lacks of political tendency related to expressing 'power' in order to apply a protection for minority citizens. Therefore, it is reasonable to propose a fundamental statement that the political power of the state should be implemented into various political methods of defending religious minority group [19].

Moreover, religious minority groups in Indonesia are victims based on their experiences as excluded groups of social and political arenas and have always been outlined from the political, societal, and governmental process. Meanwhile, radical groups have political pressure, on the one side, political exclusion has been considered as a strong issue relating to religious minority groups in Indonesia. By supporting the majority, they can unilaterally restrict religious minority's access to enjoy justice and protection. In fact, repressive majority groups can determine which strategies can be used to cut off the religious minority group's expressions and interests. Their political pressures are manifested in the form of public policy and legal provisions that restrict the presence of religious minority groups.

What the Ahmadiyya group and other religious minority groups have experienced in Indonesia reflects on the political position of Indonesia's government. Government does not ensure a protection to religious minority groups and they are excluded from any of the state's fundamental concerns. The uncertainty of religious minority groups illustrates the state's political inconsistency as a source of discrimination and violation. The national state's weaknesses are exposed in cases where the local government oppresses religious minority groups 
and lacks the power to guarantee the enjoyment of basic rights by religious minority groups. The state is in a passive position when radical groups violate religious minority groups [20].

Political exclusion therefore similarly expresses a systematic domination of the majority. This defines the alienation process of religious minorities from political process and arena. Political exclusion refers to the limited access for minorities for getting social, political, and cultural benefits in the democratic process [21]. At a basic level, political exclusion connects the position of religious minorities and the state's inability to protect and guarantee religious minorities' rights. They have experienced automatic bias of uncertainty protection.

Political exclusion describes the absence of religious minorities in the socio-politico spheres. This situation is caused by a majoritarian domination model that influences strongly political process. Yet, it is important to support participation of religious minorities in the construction of democratic institutions [22]. However, this argument can face political restriction from the majority. The exclusion of religious minorities occurs when the needs and hopes to have free and fair access to the public policy making cannot be guaranteed by the government.

Moreover, the central problem of exclusion is the state's lack of political and judicial guarantee for religious minorities. Through this situation, other groups force religious minorities to discharge their existence from the political processes. It has nothing to do with the concept of 'equality of opportunity'. It is related to the inconsistent position of the state for protecting religious minorities. Meanwhile, the tyranny of the majority is manifested into a series of actions from the state that do not accommodate a freedom of expression of religious minorities. Religious minorities can not gain political benefits of democratic transition, meaning there is an absolute social exclusion of religious minorities due to the majority tends to dictate a comprehensive political process.

However, the majority tyranny excludes religious minorities from politics and development and leads to the construction of undemocratic practices. As the undemocratic atmosphere develops, social exclusion causes tensions between the minority and majority. The majority domination strengthens a power consolidation that potentially controls and monopolize democratic process and the state. A structural approach to a consolidation from the majority will describe clearly on how minorities are being excluded from the process of public policy-making and comprehensive development process.

It is argued that the majority tyranny mechanism spreads and 
strengthens constantly a social exclusion of minorities. Furthermore, the majority tyranny uses a background, perspective, and ideological reasons of political, economic, social identity, and social stratification for excluding minorities. Thus, it becomes logic that political exclusion can also be found in many predicament that threaten religious minorities.

The tyranny of the majority will actualize a very narrow free political space for religious minorities who are socially and politically marginalized. Thus, a measure of the democratic quality of any democratic transition is to what extent minorities are able to access not only public policy but also public civic spaces to claim their basic citizenship rights. It is important at this point to look at how these efforts of religious minorities for justice and equality in Indonesia in recent years can be understood.

\section{Religious Minorities and the Problem of} Protection

The future of religious minorities in Indonesia needs political incentives and a social support [23, 24]. The regulatory system should recognize the status of religious minorities' demand for a decisive political protection from the state. It is shown that a democratic transition needs to be perceived as including the responsibilities of the state for prosecuting violations (violators) against religious minority groups. Unless the definition of 'democratic transition' includes such a provision, there is no guarantee that an open framework for non-state actors will be constructed under a multiparty democratic and decentralized government. It is given the concern of the international community, national, and regional civil society networks to ensure that minorities, including religious minorities, can fully participate to cope in making democratic transition meaningful, this issue is of wider concern beyond those directly affected [25].

In Indonesia, it is the democratic state that is the main actor in determining the religious minority communities' ability to express freedom of faith and enjoy the benefits of the wider democratic transition trajectory. Indonesia demands a clear position Indonesia's government in challenging the tendencies of the growing violence and discrimination against religious minority communities.

Therefore, democratic government should enforce law in support of religious minorities obtaining the benefits of democratic transition, as well as judging the perpetrators of violation against religious minority communities. It could be based on Sharpe's argumentation:

Beyond the right to vote, a healthy democracy can only exist within a legal and political framework that allows for free and open debate on public issues and protects the values of individual 
dignity, autonomy, and freedom of choice. Freedom of thought and religion and the rights to equality and the protection of life, liberty, and security of the person are the necessary conditions for democracy [26].

One of the basic important challenges in democratic transition is the political movement to protect religious minorities. Ideologically, Indonesia has a very strong base in recognizing and protecting the existence of religious minorities. And yet, Indonesia still has to take some important steps to implement the recognition of religious minorities. Indonesia requires a strong political strategy from the democratic state in implementing a legal statement of protection for religious minorities. Political movement in protecting religious minorities is still eloquent in the context of democratic transition in Indonesia.

For gaining a comprehensive approach in protecting religious minority citizens, Indonesia's state tries to combine international covenants and national constitution as tools for constructing legal protection for religious minority groups. This is a substantial method to fulfil a legal protection for religious minority groups through the implementation of basic principles of human rights. The state is handling the development of legal protection for religious minority groups. Legal protection must ensure the presence and the expression of religious minority groups. The state might be able to provide a legal guarantee for religious minority groups and it is focusing a necessary attention on the fulfillment of the rights of religious minority groups. Religious minority groups need a social security for expressing their beliefs [27].

Following the issue of protection of religious minorities in democratic transition, in general, Indonesia has ratified several international conventions that are related to the protection of human rights [28]. Indonesia's government also set up a special law of human rights in the post-1998 era. It also provides a special instrument for the court of human rights. Indonesia also established the National Commission on Human Rights [29]. The commission has a very important role in encouraging the prosecution of crimes against humanity and strengthening awareness on human rights. The commission has a key role in supporting a legal protection for vulnerable and susceptible groups in Indonesia, specifically concerning religious minority groups.

There are several points to take in constructing legal law to minorities. The states have to construct a system of recognition and a legal protection for religious minority groups. The states have to establish legal protection for building conditions in which religious minority groups feel free from all forms 
of threats, repression, and oppression. The states must regard cultural rights on the basis of culture, religion and belief differences. The rights are also related to cultural beliefs. Every person has the right to freedom in determining their beliefs. The seeking of justice for religious minorities becomes the main point of the state' stand.

The rule of law that should be implemented to achieve political protection of every person, including religious minority communities, is the definition of democracy. The democratic state has to demonstrate political will in respecting religious minority communities regarding violent action against them. The democratic state should promote the interests of religious minority communities and the rights of religious minorities in terms of free access to the political process and public life. Specific policies must be conducted by the democratic state in securing religious minority communities, not only limited to the regulatory system but also related to the political framework at a practical level, safeguarding religious minorities' ability to express their beliefs [30].

At this point, political leadership becomes an important aspect in constructing a strong democratic state in an accordance with a protection strategy for religious minority communities, which requires a political leadership from the democratic government. Political leadership relates to the distinct ability in showing and defending the basic principle of democracy and the rule of law for respecting and protecting religious minority communities. Indeed, a national constitution that appreciates religious minority communities in belonging and expressing beliefs cannot be granted by the democratic state without a strong political leadership.

State-actors have to consolidate social capital related to the presence of moderate religious institutions in Indonesia in achieving a comprehensive approach towards protecting religious minority communities. The democratic government should build a good understanding and bridging of consciousness with several Islamic organizations that have significant political and social roles in constructing a democratic society in Indonesia. The democratic government has the opportunity to develop a strong political line in providing a warranty to the inclusive condition of religious institutions.

A constitutional requirement also reflects the position of the majority for considering religious minorities. In this case, legal protection can also be part of the majority's political consciousness [31]. Legal protection should also contains social support. The intention of legal protection is reducing violation of religious minorities by strong political and legal support [32].

The role of law in supporting religious minorities is not only as legal- 
statement but also practices level as the implementation of the legal protection formulations. The state and society have to struggle for practical problems. The state actors should expose the contents of legal protection at a practical and concrete level. The legal protection of the religious minority must relate to justice that can be achieved by religious minority groups in a concrete condition. The state has to demonstrate equal opportunity for religious minority groups by providing a warranty that they can safely express their beliefs.

\section{Concluding Remarks}

Religious minorities have been recognized as excluded groups from social and political process in Indonesia. One of the main problems mentioned in the criticism of the Indonesia's state is the negligence of the government to protect members of religious minority groups. In theory, democracy should establish a consequential political recognition and protection for religious minority groups.

Nevertheless, democracy seems to be silent and just limits to the voting aspect and does not concern with the voice aspect of religious minority groups. Although minority constituency becomes a fundamental element in the comprehensive democratic process, the member of religious minorities cannot claim and enjoy the fulfillment of basic rights and such democratic benefits as they are persecuted to keep their voices.

Political institutions do not focus on the issue of religious minorities. It is important to state that political institutions such as the parliamentary body at a national level does not take seriously the situation of religious minorities as one of the political problems of democratic transition in Indonesia. In early 2011, the religious leaders stated strongly that the Indonesian government had never demonstrated a political strategy in protecting religious minority. In this case, the democratic state has become part of the problem in failing to accomplish outstanding political protection for religious minorities in Indonesia.

At the end, a strong political position in protecting religious minority demands political leadership. It defines the connection of democratic values and political action in supporting a religious minority. Indonesia has to endorse electoral democracy in showing political representatives, parliament and government at the national and local levels that they have a strong political leadership in realizing a national constitution and regulations that connect with religious minority communities.[] 


\section{References}

[1] International Crisis Group reported restriction of the Amhadiyya in Indonesia as citizens in participating in the political arena. Data source: http://www.seasite.niu.edu/indonesian/ islam/Indonesia-Violence\%20and\%20Radical\%20Muslims.pdf.

[2] Magdalena Sepulveda et.al.2004. Human Rights: Reference Handbook. Costa Rica: University for Peace, pp. 197-203. Also see, Mark Lattimer, Director of Minority Rights Group International, said that religious minority groups in some areas suffer brutal attacks, detentions and torture horribly from time to time (ReligiousLiberty.TV, 16/10/2010). Religious intolerance is the new racism in the world.

[3] There is a similar situation between Indonesia and Bangladesh in transition time. See, iDRC (Internal Displacement Monitoring Centre) and NRC (Norwegian Refugee Council) (2009). Bangladesh:Indigenous People and Religious Minorities Still Affected by Displacement. Data source: http://www.internaldisplacement.org/8025708F004BE3B1/ (httpInfoFiles)/5E9692B6E4E0A918C12575F5004F95C3/\$file/Bangladesh_Overview_ Jul09.pdf The report was downloaded on 17th May 2013.

[4] Arriving at the State position, outside the view of the stakeholders of power in Indonesia, Donna Guest, Amnesty International Deputy Director for Asia Pacific, has a different view (Amnesty International, 7/2/2011).

[5] Tajima, Y. (2013). "The Institutional Basis of Intercommunal Order: Evidence from Indonesia's Democratic Transition.” American Journal of Political Science 57(1): 104119. Source: http://onlinelibrary.wiley.com/doi/10.1111/j.1540-5907.2012.00631.x/pdf

[6] Hall A. John Consolidations of Democracy in David Held (1993) Prospect for Democracy: North, South, East, West, London: Polity Press, Pp. 271-273.

[7] Davidson, James S., "Dilemmas of Democratic Consolidation in Indonesia" in The Pacific Review, Vol. 22 No. 3, July 2009: 293-310

[8] Indonesia has held four public elections after the Suharto regime in 1999, 2004, 2009 and 2014 with the third and fourth election referring direct presidential elections. The political progress shows the growing opportunity for direct participation of the people in Indonesia. Data source: http://www.kpu.go.id/index.php?option=com_content\&task=vie w\&id=43\&Itemid=66 the report was downloaded on 10th May 2013.

[9] Cornwall, Andrea \& Vera Schattan Coelho (2007). Spaces for Change?: The Politics of Citizen Participation in New Democracy Arenas, New York - London: Zed Books Ltd.

[10] Lussier, D. N. and M. S. Fish (2012). "Indonesia: The Benefits of Civic Engagement." Journal of Democracy 23(1): 70-84. Source: http://muse.jhu.edu/journals/jod/summary/ v023/23.1.lussier.html. It was downloaded on 25, October 2013.

[11] Freeman, Amy Freeman \& Robert Tiburzi (2012), "Progress and Caution: Indonesia's Democracy" in Asian Affairs: An American Review, 39:3, 131-156.

[12] Horowitz, L. Donald (2013), Constitutional Change and Democracy in Indonesia, New York: Cambridge University Press.

[13] Preuss, U. K. (2012). "2 Constitutionalism in fragmented societies.” Critical Theory and Democracy: Civil society, dictatorship, and constitutionalism in Andrew Arato's democratic theory: 41 .

[14] Mietzner, M. (2012). "Indonesia's democratic stagnation: anti-reformist elites and resilient civil society.” Democratization 19(2): 209-229. Source: http://www.tandfonline.com/doi/ pdf/10.1080/13510347.2011.572620.

[15] Newman, Nicholas “Indonesia: Telling Lies" Data source: http://www.worldpolicy.org/ journal/winter2011/indonesia-telling-lies. This report was downloaded on 25th May 2013. 
[16] Blair, T. (2012). "Protecting Religious Freedom Should Be A Priority for All Democracies." The Review of Faith \& International Affairs 10(3): 5-9. Source: http://www.tandfonline. com/doi/pdf/10.1080/15570274.2012.706017.

[17] Some members of the Ahmadiyyah Groups in Cikeusik, West Java, Indonesia were killed in 2011, www.amnesty.org Downloaded 3th April 2013.

[18] Human Rights Watch, In Religion's Name: Abuses against Religious Minorities in Indonesia, February 2013. Source: www.hrw.org. The report was downloaded on 16th March 2013.

[19] Malik, Iftikhar H. Malik (2002), Religious Minorities in Pakistan, Minority Rights Group International (MRGI). http://southas2.w06.wh-2.com/Media/NewsDoc/_1787.Pdf

[20] Bagir, Zainal, Analyses of Indonesia's Ahmadiyah Case, Documents, Center for Religious and Cross-Cultural Studies UGM. Source: http://crcs.ugm.ac.id/get/NUDe8. The report was downloaded on 24, October 2013.

[21] Lerner, H. (2013). "Permissive Constitutions, Democracy, and Religious Freedom in India, Indonesia, Israel, and Turkey." World Politics 65(04): 609-655. Source: http:// portal.idc.ac.il/He/schools/Government/Research/Documents/Lerner.pdf

[22] Kamens H. David New Citizens - New Models of Democracy: Theorizing the Disconect Beetween Citizens and States (Chapter 3) in Rhiannon Morgan and Bryan S. Turner (2009) Interpreting Human Rights: Social Sciences Perspectives, New York: Routledge.

[23] Located in Southeast Asia with a population of about 240 million people. Indonesia is known as the country with the largest Islamic population in around the world with 220 million people. Indonesia has approximately 17 thousand islands with diverse social, ethnic, cultural dimensions in the Center for Religious and Cross-Cultural Studies (CRCS), Annual Report on Religious Life in Indonesia, Graduate School Gadjah Mada University, Jogyakarta, Indonesia, 2009. This report was downloaded at 29/01/2013, 17:28:32

[24] Hertzke, D. Allen (2013), The Future of Religious Freedom: Global Challenges, Oxford: Oxford University Press.

[25] Kaltwasser, C. R. (2013). "The Responses of Populism to Dahl's Democratic Dilemmas." Political Studies. Source: http://onlinelibrary.wiley.com/doi/10.1111/1467-9248.12038/ pdf (23 oct)

[26] Sharpe, R. J. (2013). “The Foundation for Law, Justice and Society.” Source: http://www. fljs.org/sites/www.fljs.org/files/publications/Sharpe.pdf

[27] Sharma, A. (2012). Introduction. Problematizing Religious Freedom, Springer: 3-15.

[28] International Covenant on the Elimination of Racial Discrimination (CERD) was ratified on July 25, 1999. National Instruments is the Law. 29 of 1999; International Covenant on Civil and Political Rights Supervisory Board: Human Rights Committee (CCPR), which was ratified on 23-May-2006 National Instruments: Law Number. 12 of 2005.

[29] The Law Number 39 of 1999 on Human Rights Law Number 26 of 2000 on Human Rights Court. Both of these laws were made by the Council of Representatives after the reform. Two laws are part of the significant progress of legal reform in Indonesia.

[30] Lars Binderup, Liberty Equality - From Minority Rights to the limits of Tolerance, Res Cogitans, No. 4, Vol. 2, 2007.http://static.sdu.dk/mediafiles/Files/Om_SDU/Institutter/ Ifpr/rescogitans/vol41/RRR\%20\%20\%20Binderup.pdf Accessed, March, , 6, 2014.

[31] Crouch, Melissa A., (2012) "Law and Religion in Indonesia: The Constitutional Court and the Blasphemy Law," Asian Journal of Comparative Law: Vol. 7: ISS. 1

[32] Khan, Irene.2009. 'Claiming Rights: Legal Empowerment to End Poverty “in The Unheard Truth: Poverty and Human Rights, New York, Norton, pp. 201-221. 